\title{
SUSTAINABLE HUMAN RESOURCE MANAGEMENT AND ITS MODELS
}

\author{
Barbara Mazur*
}

\begin{abstract}
Background. During the last decade, a new approach to Human Resource Management (HRM) has evolved. This approach, called Sustainable Human Resource Management (Sustainable HRM), seeks to link HRM and sustainability.
\end{abstract}

Research aims. This paper examines the meaning ascribed to sustainability and the relationship between sustainability and HRM. It outlines the major characteristics of sustainable HRM. The main objective of the paper is to present two models of Sustainable HRM.

Methodology. The article is a theoretical review. It consists of a current literature analysis. The first part of the paper presents the concepts of and relationships between sustainability and HRM. The second part presents the Three Pillars Model of Sustainable HRM: work-life balance, personal autonomy in professional development, and employability of the workers; as well as the Holistic Model of Sustainable HRM consisting of psychological, sociological, strategic, and ecologic approaches. Finally, a conclusion resulting from the comparison of the models is delivered.

Key findings. The two models presented in this paper can be applied in analysis and empirical study. However the choice of the model for study should depend on the purpose of the study and the size of the audited company.

Keywords: sustainability, HRM, model, sustainable HRM.

\section{INTRODUCTION}

A new approach to Human Resource Management labelled Sustainable Human Resource Management has evolved. This approach explicitly recognizes the impact people management policies have on both human and financial outcomes. The literature on sustainable HRM

\footnotetext{
* Lublin University of Technology. E-mail: b.mazur@pollub.pl
} 
has developed during the past decade and it represents an attempt to grapple with the relationship between HRM practices and outcomes beyond predominantly financial outcomes (Kramar, 2014, p. 1070). This approach explicitly recognizes the legitimacy of organisational practices, particularly HRM practices, in furthering a wider range of outcomes. These outcomes could include impacts on individuals or groups within an organisation (human outcomes) and impacts on groups of people and the relationships between people (social outcomes). This alternative approach also includes the impact of HRM on ecological/ environmental outcomes. Although there are various views regarding sustainable HRM, many researchers accept Ehnert's definition (2009, p. 74), according to which sustainable HRM is "the pattern of planned or emerging human resource deployments and activities intended to enable a balance of organizational goal achievement and reproduction of the human resource base over a long-lasting calendar time and to control for negative impact on the human resource base". According to others, sustainable HRM represent a new approach to managing people and offers an opportunity to improve management practice (Kramar, 2014, p. 1085) and extend the grounding that sustainability is an appropriate concept for HRM. (Stankeviciute \& Savaneviciene, 2013, p. 843). It proves the relevance of implicating the sustainability concept into HRM.

\section{INTERPRETATIONS AND CONNECTIONS BETWEEN SUSTAINABILITY AND HRM}

Noticeable difficulties are linked to the definitions of terms: Sustainability and HRM exist on a semantic level. There are no definitive descriptions and the meanings of the existing ones range in accordance with the determinants enclosing their consideration. These determinants include the presumptions and suppositions, theoretical groundworks, stakeholder interests, the time frame used and the national and industrial contexts in which the conceptions are examined.

The very term 'sustainability', rather general and inaccurate (Kramar, 2014, p. 1075), has been developed since its application in the contexts of the environment. The discourse concerning sustainability was inflamed by the Brundtland Commission of the United Nations. 
The Brundtland Commission adopted an extensive view of sustainable evolution which was global, long-term and included a variety of stakeholders. It recognised three pillars of sustainable development: economic, social, and environmental. This attitude reflected not only the Commission's concern for the deterioration of the natural environment, but also the concern for the social impact and continued waste of HRs resulting from the prevailing nature of economic growth and development (Brundtland, 1987). The Brundtland idea of sustainability caused interest in a range of concepts concerned with the responsibilities of business. These concepts include corporate social responsibility (CSR). The basis of CSR is that organisations carry not only economic and legal, but also ethical and philanthropic responsibilities. By their very nature, when these concepts of responsibility are considered within the context of work organisations, they require consideration of the impact of organisational activities on a number of stakeholders. They also allow an assessment of organisational outcomes, performance and impacts extending beyond just the financial and economic arena (Mazur, 2015).

The Brundtland approach has been applied to organisations and businesses and may be viewed as one way of comprehending sustainability in the world of business. This approach builds on the concept of the three pillars by proposing that three organisational outcomes: financial performance, social and ecological/environmental impacts, need to be considered as dimensions of organisational performance (Elkington, 1997). It perceives sustainability in terms of short- and longer-term impacts on an array of stakeholders.

The vast term HRM refers to the activities linked with managing the people who work for organisations. This view of HRM surpasses the definition of Boxall and Purcell (2008) who describe HRM in terms of activities associated with employees' management. Nonetheless, more and more work is being done by people who are engaged on contracts other than the employment contracts. The character of HRM is expanded by acknowledging that HRM is linked with more than just managing employees: it shall also involve managing people such as sub-contractors, consultants, and people hired on the basis of nonemployment contracts, as well as (if possible) taking care of the management of other organisations in the production of goods and services. According to Ehnert and Harry (2012), the relevance of sustainability as a concept for HRM can be supported by two kinds 
of arguments: first, every organisation operates in economic, legal, and social environments and HRM not only can no longer neglect the societal discussion on sustainability, but needs to make an input to sustainable development; second, due to the scarce human resources, aging population and increasing work-related health problems, sustainability of HRM itself becomes essential for the surviving of organisations. In the light of the perspectives on it, one is inclined to wonder about the meaning of Sustainable HRM.

\section{Literature review on Sustainable HRM}

The very term 'sustainable HRM' has been used for more than a decade. The literature is piecemeal, diverse, and fraught with difficulties (Ehnert, 2009). There is no one precise definition of the term and it has been used in a variety of ways. The writings on sustainable HRM differ in terms of the emphasis given to particular internal and external outcomes. It has been used to refer to social and human outcomes which contribute to the continuation of the organisation in the long-term, that is to a sustainable organisation. It has also been used to refer to HRM activities which enhance positive environmental outcomes Green HRM (GHRM), and positive social and human outcomes for their own sake, rather than just as mediating factors between financial outcomes and strategy (Mazur, 2016). As with the terms HRM, SHRM, and sustainability, there are definitional issues with the term sustainable HRM.

A number of terms have been used to link sustainability and HRM activities (Kramar, 2014). These include sustainable work systems (SWSs), HR sustainability, sustainable management of HRs, sustainable leadership, and sustainable HRM (Ehnert, 2009). In addition, the term sustainable organisation has also been used. Although these terms differ in the extent to which they attempt to reconcile the goals of economic competitiveness, positive human/social outcomes and ecological outcomes, they are all concerned with acknowledging either explicitly or implicitly the human and social outcomes of the organisation. They all recognise the impact HR outcomes have on the survival and success of the organisation.

A common feature of the writings on sustainable HRM is that HRM practices contribute to the development of the human and social capital within the organisation. In addition, some of these 
writings also acknowledge that there is a growing concern for the impact of HRM policies on externalities, such as the environment and social and human aspects of society. Some of this literature also acknowledged that HRM practices will influence the extent to which people are attracted to work for an organisation or to purchase its products and services.

The literature on sustainable HRM can be categorised into three groups (Ehnert, 2009). A common feature of all of these groups is an understanding that sustainability refers to long-term and durable outcomes. However, the writers in these various categories understand sustainability and its relationship to HRM in different ways. The groups are categorised in terms of their outcomes. One group emphasises economic outcomes and the creation of 'sustainable competitive advantage'. This group focuses on the internal impacts of HRM policies. Another group emphasises the external outcomes, such as broader performance outcomes including ecological/environmental and/or social and human outcomes. A third group moves beyond just HRM practices and examines the interrelationships between management practices, including HRM and organisational outcomes, which consist of environmental and social outcomes. This includes the literature on sustainable leadership. This literature acknowledges the influence of national contexts on management practices while the literature on sustainable organisation explores the relationship between HRM policies and environmental sustainability and is concerned with the explicit connections between a variety of internal and external outcomes and HRM practices. These groups are not mutually exclusive. Although these three categories provide a simple means of drawing out the major distinctions between the writings on sustainable HRM they have a common feature. It is an understanding that sustainability refers to a long-term and durable outcome (Kramar, 2014, p. 1076).

\section{Models of Sustainable HRM}

A body of knowledge on sustainable HRM is continuously developing. However the challenge of integrating these into management practice in the workplace is problematic (Kramar, 2014, p. 1085). Literature highlights a number of possible approaches for research and the possible practice of HRM based on the models. 
Interpreted in its broadest sense, a model is just a simplified image of some object under study. Modelling will mean the art of constructing and using such models as tools for analysing policy alternatives and evaluating operations (Vemuri, 1978). It aims at increasing the understanding of how systems function and make it possible to predict their response to different changes. The objectives of modelling may be more or less operational. Sometimes models are developed in order to provide prognoses, or to evaluate decision alternatives. Often, however, the purpose is just to use the model as a tool for developing a deeper insight into the properties of a system (Lagergren, 1998, p. 258). This insight could then be used for policy design or evaluation.

The literature in the field of sustainable HRM proposes some useful models. Two of them "The Three Pillars Model of Sustainable HRM" and the other named 'Holistic model of Sustainable HRM' will be characterised in this part of the article.

\section{The Three Pillars Model of Sustainable HRM}

The term sustainable HRM has been conceptualised in a variety of ways. According to Zaugg, Blum, and Thom (2001), sustainability in the management of people is built on three pillars: work-life balance, personal autonomy in professional development, and employability of the workers. The underlying objectives of the conceptual model of sustainable human resource management are the following: 1) increasing the employees' employability, 2) using participatory management models to enhance individual responsibility, and 3) ensuring a harmonious work-life-balance.

The achievement of these objectives is possible if the individual and the company are considered as equal partners. Therefore measures for sustainable human resource management concern the individual as well as the company. By sustainable human resource management satisfaction of individual needs is promoted and maintaining the competitiveness of a company is supported.

A detailed analysis of the model's elements was delivered by G. Pipoli, R.M. Fuchs and M.A. Priale (2014, pp. 359-375). They also conducted a research in Peruvian companies based on the model. Their interpretation of the three elements of Sustainable HRM models are cited below (Figure 1). 


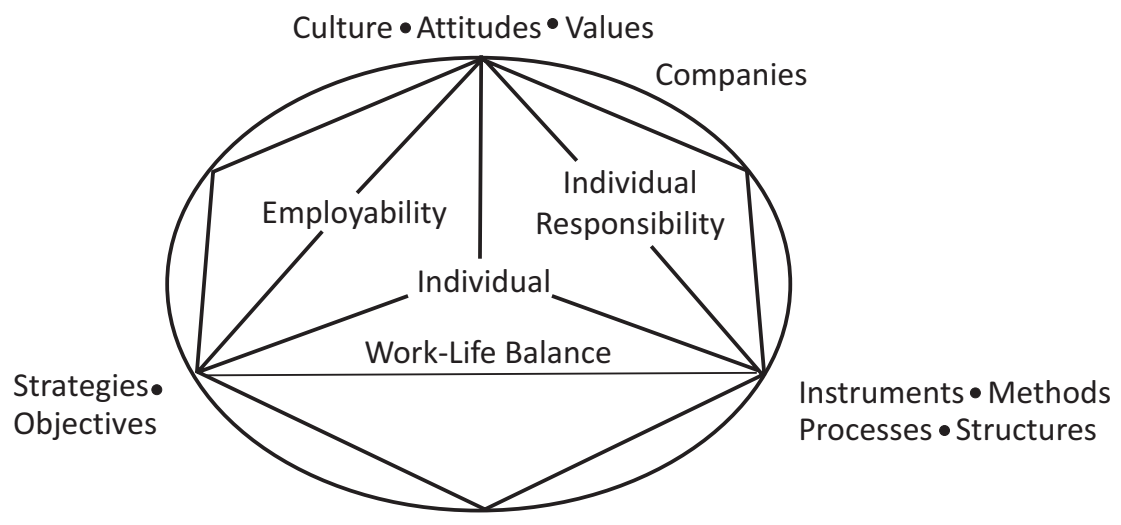

Figure 1. Model of Sustainable Human Resource Management

Source: based on Zaugg et al., 2001, p. 3 .

Personal autonomy in professional development is commonly thought to be positively related to organisational commitment and reduces absenteeism. The reason why autonomy is important to workers is that it provides them the freedom to perform their work independently. Work autonomy has been defined as the degree to which the job provides substantial freedom, independence, and discretion in scheduling the work and in determining the procedures to be used in carrying it out. Work autonomy influences an employee's perception of their authority to accomplish different demands. Work exhaustion, low satisfaction, and reduced productivity are often the outcome of a lack of autonomy at work. Studies suggest that autonomy influences individual perceptions of the workplace and affects employees' behaviour. Autonomy provides employees with the freedom and flexibility to manage their own tasks. According to Pipoli et al. (2014), increased levels of autonomy will allow individuals greater flexibility in how they define their tasks because they will decide how to perform the work.

Employability of the workers may be defined as being capable of getting and keeping a fulfilling job. More comprehensively, employability is the capability to move self-sufficiently within the labour market to realise one's potential through sustainable employment. It should be clarified that workers employability depends on personal circumstances such as family responsibilities, work autonomy, and flexibility to manage balance between work and family and external factors. 
Employability not only depends on fulfilling the requirements of a specific job, but also on how one person is more capable of developing specific work and how he/she stands relatively to others. It is important to recognise that employability will vary according to the economic conditions and growth of organisations. Employability may as well be described as the relative chances of finding and maintaining different kinds of employment according to the circumstances. In fact, according to Pipoli et al. (2014), the current changing of career partners has resulted in a growing focus on employability as a basis for the career and employment success.

Work-life balance is commonly defined as the growing recognition that individuals require a satisfactory balance between the demands of work and other aspects of life. What is important is that there is a need to recognise that individuals require a satisfactory balance between work and personal life for better performance. The emphasis on work-life balance is shifting from being merely the concern of employees to a joint responsibility between the employer and the employee. To manage work-life balance, it has to be stated that workers need to build support networks at home and work, because studies demonstrate that an inadequate balance between work and family has negative consequences and affects both an employee's performance and home relationships. Therefore, options to facilitate this balance are work-life programs to retain employees; but companies also have to find the best way to communicate them. If a company already offers work-life benefits, the next step may be to communicate to employees this offer. "In addition, developing a human resources strategy that is clearly integrated with the company's mission will demonstrate how committed the organization is to employees' needs" (Lockwood, 2003, p. 6). Furthermore, for work-life benefits, it is commonly thought to be helpful to have a corporate culture that supports and accepts employees as individuals with priorities beyond the workplace. Employees who experience high rates of stress due to work/life conflict and decreased perceptions of control over their work are less productive, show less commitment and satisfaction with their organisations and are more likely to leave the organisation. On the other hand, it is commonly believed that employees with low rates of work-life conflict have higher job satisfaction.

In conclusion, work/life programs have the potential to improve employee satisfaction, reduce turnover, and retain potential employees. 
Therefore, Pipoli et al. (2014) suggest that when employers and employees perceive work-life balance as a priority and feel that there is a positive balance between family and work, employees tend to stay in the organisation.

\section{The holistic model of Sustainable HRM}

One of the most interesting attempts to capture the complexity of the concept of Sustainable Human Resource Management is De Prins' holistic model consisting of four approaches to Sustainable HRM (Rompa, 2011, pp. 15-17).

De Prins (2011) argues that Sustainable HRM focuses on optimally utilising and respecting human workforces within the organisation, in which an explicit relationship is built between an organisation's strategic policies and its environment. De Prins distinguishes four approaches to the concept, of which the first, second, and fourth are exhibited in concrete policies: sociological, psychological, strategic human resource management, and green approaches,

The Sustainable Human Resource Management framework including all those approaches is depicted in the Figure 2.

A detailed analysis of the model's elements was delivered by I. Rompa (2011, pp.16-17). She also conducted a research in European companies

\section{Sustainable HRM Framework}

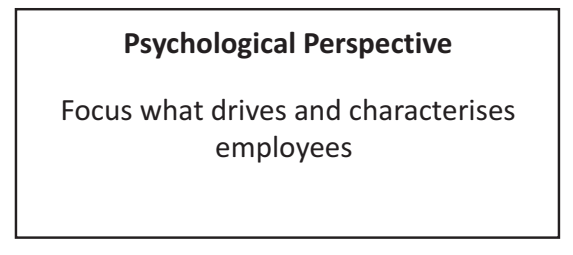

Strategic Perspective

HR's contribution to the long-term focus of the organisation as a whole

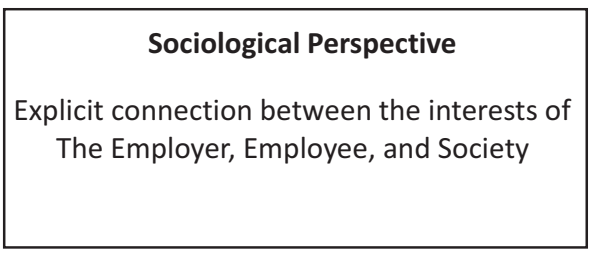

Green Perspective

Employee Society

Employee management and the Planet

Figure 2. The holistic model 
based on the model. Her interpretation of the four perspectives of Sustainable HRM holistic model is cited below.

The sociological approach intends, as the very name suggests, to make HRM a more social practice. This particular model of administration has its focal point at continuity. The interests and involvement of three components - the employee, the employer, and the society - are clearly interconnected. Of significant importance are such ideas as: engagement policies, health policies, and societal themes like diversity, age-conscious and family-friendly personnel policies.

The psychological approach focuses on the employee, precisely on what subject matters he or she recognises as relevant. As stated by De Prins, if people are at the centre of attention of a sustainable competitive advantage, then the knowledge and fostering of what drives and characterises them is of ultimate significance. People differ totally from financial or technological capital because they act in time, seek intention and have a soul. Within this model, the crucial points are: work-life balance, autonomy, self-development, employability and dialogue.

Another approach, strategic perspective on Sustainable HRM, examines how Sustainable HRM and strategic HRM are connected. The attention is aimed on the influence that Sustainable HRM has on conventional HR spheres: recruitment and selection, employee turnover, appraisal- and employability-aspects of an organisation. Ehnert's definition of Sustainable HRM to describe this approach indicates that HR aims at achieving organisational goals, which entail more than benefits only. Typical themes are: the belief in humans as a sustainable competitive advantage, social achievements and the sustainable management of HR sources. Nevertheless, one should bear in mind that the stipulations of the related policies are still being reviewed.

The last approach - Green HRM - concerns the approaches of the employees and management to the planet-component of the triple bottom line - which HRM aspects can help to make the organisation "green". What is more: how does the 'green character' affect the employer's attractiveness and branding. Relevant themes are mentioning green behaviour as a competence, training in sustainability awareness, stimulating environmentally conscious behaviours, and green employer branding. 


\section{FINAL REMARKS}

Over the last decade an increasing scholarly interest in Sustainable HRM in managerial literature has occurred. The purpose of this paper is to provide an opportunity to have a deeper insight into the sustainable way of managing employees in the light of this literature. As a result of a literature review, two models of sustainable HRM were enumerated. The Three Pillars of Sustainable HRM - was the first model to emerge. It is narrower in scope than the second approach. It can be successfully applied in the study of national organisations and that is how it was first applied: sustainable HRM in organisations within individual European countries was studied and they were compared with its help. The second model is broader in its nature, that is why it is called holistic. Because of its characteristics, it can be successfully used in the research concerning the use of sustainable HRM in multinational and global companies. It seems, therefore, that the two models presented in this paper can be applied in analysis, however the choice of a model for study should depend on the purpose of the study and the size of the audited company.

Nevertheless, the sustainable HRM theory seems fragmentary and incoherent, while the practical dimension requires developing. Sociology, systems science, and public health are among the numerous fields that may offer substantial potential for academic research regarding sustainable HRM.

\section{REFERENCES}

Boxall, P. \& Purcell, J. (2008). Strategy and Human Resource Management. Palgrave Macmillan.

Brundtland, G. (ed.) (1987). Report of the World Commission on Environment and Development: Our Common Future. Oxford: Oxford University Press.

De Prins, P. (2011). DUURZAAM HRM: synthetische academische introductie, cited by: Rompa I., Explorative Research on Sustainable Human Resource Management. http://www. innovatiefinwerk.nl/sites/.../sustainable_hrm. pdf (access: 10.01.2015). 
Ehnert, I. (2006). Sustainability issues in human in human resource management: linkages, theoretical approaches, and outlines for an emerging field. In: 21st EIASM SHRM Workshop, Aston, Birmingham, March 28-29.

Ehnert, I. (2009). Sustainable Human Resource Management: A Conceptual and Exploratory Analysis from a Paradox Perspective. Heidelberg-London-New York: Springer.

Ehnert, I. \& Harry, W. (2012). Recent developments and future prospects an sustainable human resource management: Introduction to the special issue. Management Review, 23(3), 221-238.

Elkington, J. (1997). Cannibals With Forks: The Triple Bottom Line of the 21st Century. Oxford: Capstone.

Kramar, R. (2014). Beyond strategic human resource management: is sustainable human resource management the next approach? The International Journal of Human Resource Management, 25(8), 1069-1089.

Lagergren, M. (1998). What is the role and contribution of models to management and research in the health services? A view from Europe. European Journal of Operational Research, 105, 257-266.

Lockwood, N.R. (2003). Work-life balance: Challenges and Solutions. Alexandria, VA: Society for Human Resource Management Research Quarterly.

Mazur, B. (2015). Corporate social responsibility in Poland: Businesses' self-presentations procedia. Social and Behavioral Sciences, 213, 593-598. 20th International Scientific Conference : Economics and Management 2015 : ICEM'2015, Kaunas, May 6-8, 2015.

Mazur, B. (2016). Green human resource management. In: B. Kożuch \& K. Sienkiewicz-Małyjurek (eds.), Faces of Contemporary Management. Kraków: Jagiellonian University Press, 11-21.

Pipoli, G., Fuchs, R.M. \& Priale, M.A. (2014). Sustainable HRM in Peruvian companies. An exploratory study. In: I. Ehnert, W. Harry \& K. Zink (eds.), Sustainability and Human Resource Management. Developing Sustainable Business Organizations. Berlin-Heidelberg: Springer-Verlag.

Rompa, I. (2011). Explorative research on sustainable Human Resource management. http://www. innovatiefinwerk.nl/sites/.../sustainable_hrm.pdf (access: 10.01.2015).

Stankeviciute, Z. \& Savaneviciene, A. (2013). Sustainability as a concept for human resource management. Economics and Management, 18(4), 837-846.

Vemuri, V. (1978). Modeling of Complex Systems. San Diego: Academic Press.

Zaugg, R.J., Blum, A. \& Thom, N. (2001). Sustainability in Human Resource Management: Evaluation Report. Bern: IOP-Press. 


\section{MODELE ZRÓWNOWAŻONEGO ZARZĄDZANIA ZASOBAMI LUDZKIMI}

\section{Abstrakt}

Tło badań. Od ponad dekady w literaturze na temat zarządzania można znaleźć publikacje poświęcone nowemu podejściu do zarządzania zasobami ludzkimi. Podejście to, nazwane zrównoważonym zarządzaniem zasobami ludzkimi, łączy zarządzanie zasobami ludzkimi z koncepcją zrównoważonego rozwoju.

Cel badań. Celem artykułu jest prezentacja koncepcji zrównoważonego zarządzania zasobami ludzkimi w świetle analizy relacji pomiędzy zrównoważonym rozwojem a zarządzaniem zasobami ludzkimi oraz przedstawienie dwóch modeli charakteryzujących to zarządzanie.

Metodologia. Artykuł oparty jest na przeglądzie dostępnej literatury. Ma on charakter teoretyczny.

Kluczowe wnioski. W świetle cytowanej literatury zasadne jest odniesienie zasad zrównoważenia do zarządzania zasobami ludzkimi. Dowodzą tego dwa modele znajdujace zastosowanie w praktyce zarządczej. Ich wybór i zastosowanie powinny być jednak zdeterminowane celem oraz wielkością samej organizacji.

Słowa kluczowe: rozwój zrównoważony, ZZL, model, zrównoważone ZZL. 